\title{
The Phototextual Emergence of Hysteria: From the Iconographie Photographique de la Salpêtrière to J. M. Coetzee's Slow Man
}

\author{
IONA GILBURT \\ Centre for Humanities Research, University of the Western Cape \\ https://orcid.org/0000-0002-6141-451X
}

\begin{abstract}
This article seeks to examine the emergence of the image of hysteria that originated at the Salpêtrière Hospital in Paris in the late nineteenth century and has since been transferred across new generations of phototexts through ekphrasis. It is first shown how this stereotypically feminine and sexualised image was initiated by the medical tome Iconographie Photographique de la Salpêtrière - an effect that belies the physicians' original intentions - and is then taken up in the public imagination by the surrealists André Breton and Louis Aragon before emerging in Georges DidiHuberman's 1982 critical text Invention of Hysteria. Didi-Huberman's monograph offers insight into how persistent this image becomes, even taking shape in discourses that attempt to undermine it. Didi-Huberman furthermore highlights how developments in photographic technology have contributed to the shaping of hysteria. Finally, this article considers how the figure of the hysteric appears in J. M. Coetzee's 2005 novel Slow Man in the character of Marianna. The manner in which she is depicted presents an ekphrasis that can be matched to the vision of hysteria that began with the Iconographie Photographique de la Salpêtrière, thereby showing how this histrionic and gender-stereotyped iteration of hysteria from the nineteenth century remains a readily accessible mode of expression.
\end{abstract}

\section{Introduction}

The life of the photograph continues beyond its visual iterations as the image moves into prose and critical discourse, living in what Ari J. Blatt terms 'phototexts - those composite works or concepts that combine photographs and words.' There are many types of phototexts, but this article focuses on two iterations of the genre: written texts that include reprints of photographic images, and a literary text that references photography without including actual photographic prints. For readers, the encounter between word and image produces a new conceptualisation of the source photograph as 'he or she generates superimpositions, collages, and montages that make

1 A. J. Blatt, 'Phototextuality: Photography, Fiction, Criticism', Visual Studies, 24, 2, September 2009, 113. 
up a palimpsestic image.' This new mental image, which is a coproduction between reader and text (monograph, novel), falls within ekphrasis, as articulated by Nigel Krauth and Christopher Bowman, who return to its original use as a type of 'mind image' crafted during rhetorical exercises. 'To excel at ekphrasis', they note, 'the writer had to perfect the transfer of an image created from reality in their own mind, to the mind of another.' ${ }^{3}$ The mind image is transferred to the reader, yet the creator is not in full control of how it is perceived because an ekphrasis 'is a virtual image engineered by the text and reinvented by the reader; it will never exactly coincide with the narrator's.' As will be explored, the journey of such a 'mind image' stimulated by the encounter with the phototext encapsulates how the afterlife of a photograph can exceed and complicate the ostensible intention behind its creation.

In this article, I intend to trace the emergence of the 'mind image' of hysteria that originated in late-nineteenth century Paris with the publication of the Iconographie Photographique de la Salpêtrière: a medical text showing photographs of patients at the Salpêtrière Hospital in Paris who were diagnosed with hystero-epilepsy (hysteria) and epilepsy. ${ }^{5}$ The volume was produced by physician Désiré-Magloire Bourneville, with photographs by medical intern Paul Régnard, under the direction of the imposing figure of Jean-Martin Charcot, who is still referred to often as the father of neurology and known as the 'Napoleon of the Salpêtrière.' ${ }^{6}$ The Salpêtrière, named after saltpetre (a chemical in gunpowder that it manufactured in its original role as ammunitions store), was a formidable compound that housed eight thousand people in forty-five buildings and was 'effectively a town in its own right, covering 100 acres with streets, squares, gardens and an old church.' The Iconographie Photographique de la Salpetrière (hereafter abbreviated to Iconographie) ${ }^{8}$ was intended to serve a key role in recording the physicians' concept of hysteria. Yet, as will be shown, the perception of hysteria it initiated came to undermine Charcot's project at the Salpêtrière.

When Charcot turned his attention to hysteria, it was a perplexing condition expressed in intermittent symptoms that 'frequently included excessive laughing or crying, wild bodily movements, paralysis, numbness, or temporary deafness and blindness', hyper-sensitivity to touch, fainting spells, as well as 'a predilection for drama and deception. ${ }^{9}$ Today, several of these women would likely be diagnosed with illnesses such as schizophrenia, bipolar disorder, and anorexia, among others, but in the nineteenth century their conditions were grouped haphazardly under an increasingly unstable umbrella term: 'Located on the problematic border between psychosomatic and somatic disorders, hysteria was a confusion of real and imagined

L. Louvel, 'Types of Ekphrasis: An Attempt at Classification', Poetics Today, 39, 2, June 2018, 259.

N. Krauth and C. Bowman, 'Ekphrasis and the Writing Process', New Writing, 15, 1, 2018, 13.

L. Louvel, 'Photography as Critical Idiom and Intermedial Criticism', Poetics Today, 29, 1, Spring $2008,45$.

D.-M. Bourneville and P. Régnard, Iconographie Photographique de la Salpêtrière (Service de M. Charcot). (Paris: Progres medical/Delahaye and Lecrosnier, vols 1-3: 1877-9), vol 2 is available at: https://archive.org/details/b21912865_0002/page/6/ mode/2up (accessed 31 July 2020).

6 A. Hustvedt, Medical Muses: Hysteria in 19th-Century Paris (London: Bloomsbury, 2011), 'Part Three: Augustine', unpaginated Kindle edition.

7 A. P. Wickens, A History of the Brain: From Stone Age Surgery to Modern Neuroscience (London and New York: Psychology Press, 2015), 249

$8 \quad$ My analysis examines the second volume, which contains Figures 1 and 2.

9 Wickens, History of the Brain, 255. 

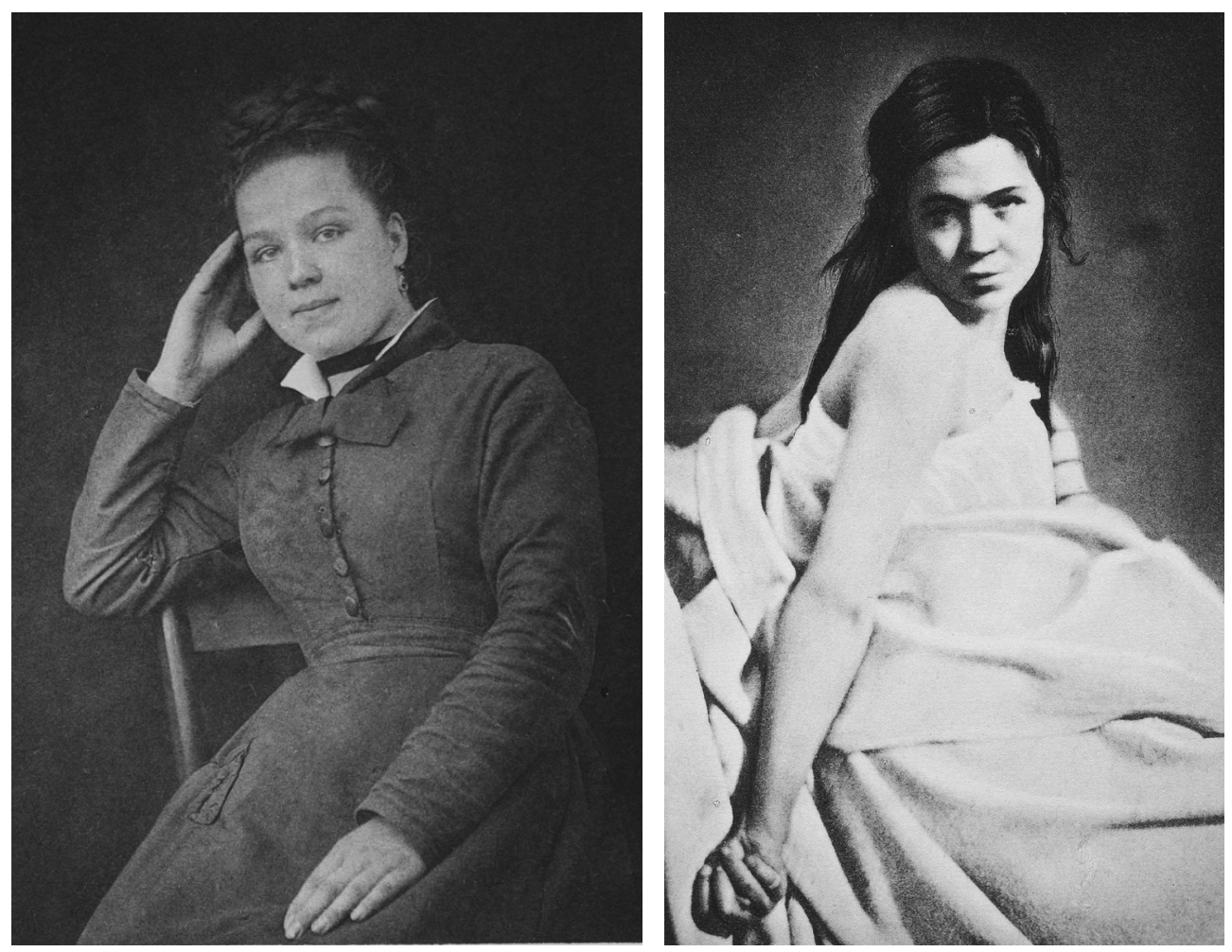

Figure 1 (above left): 'Hystero-Epilepsy: Normal State', Photograph by Paul Régnard. Iconographie Photographique de la Salpêtrière, vol 2, 1878. Photograph courtesy of Yale University, Harvey Cushing/John Hay Whitney Medical Library.

Figure 2 (above right): 'Hystero-Epilepsy: Contracture', Photograph by Paul Régnard. Iconographie Photographique de la Salpêtrière, vol 2, 1878. Photograph courtesy of the Wellcome Collection. Attribution 4.0 International (CC BY 4.0).

illness. In an era without demons and before Freud's unconscious, hysteria fell into a theoretical vacuum. ${ }^{10}$ Charcot would become obsessed with trying to understand and clarify this elusive ailment. Although he had been successful in defining conditions such as multiple sclerosis by employing the anatomo-clinical method (using autopsies to match behavioural symptoms to 'physiological abnormalities at death'), ${ }^{11}$ hysteria would prove to be far more challenging.

Charcot proposed that psychologically traumatic events ('dynamic lesions') acted as catalysts in patients with 'a hereditary propensity for nervous disease', but, as he found no pathological evidence for the illness, 'Charcot's characterization of the disorder relied upon visually observable signs, through which its fundamental structure was deemed detectable. ${ }^{12} \mathrm{He}$ insisted that the hysterical attack 'followed a completely

10 Hustvedt, Medical Muses, 'Part One: Charcot'.

11 Wickens, History of the Brain, 249.

12 D. de Marneffe, 'Looking and Listening: The Construction of Clinical Knowledge in Charcot and Freud', Signs, 17, 1, Autumn 1991, 75-6. 
regular and uniform pattern' in all his patients. ${ }^{13}$ These attacks were demonstrated publicly during Charcot's famous Tuesday lectures. Under hypnosis, hysterics enacted their symptoms dramatically in a large amphitheatre that was the first in Europe equipped with facilities to project photographic slides onto a large screen. ${ }^{14}$ The demonstrations became a popular spectacle that overtook the public imagination:

Stories about hysterical patients filled the columns of newspapers. They were transformed into fictional characters by novelists. Hysterics were photographed, sculpted, painted, and drawn. Every week, eager crowds arrived at the hospital to attend Charcot's demonstrations of hysterics acting out their hysterical symptoms. And it wasn't only medical students and physicians who came to view the shows, but artists, writers, actors, socialites, and the merely curious. ${ }^{15}$

But the disorder's exoticism coupled with 'the theatricality of his clinical demonstrations was to make Charcot many enemies. ${ }^{16}$ Although Charcot is often lauded for much of his other work at the Salpêtrière, his work on hysteria never seemed to take on the legitimacy he had hoped to afford it. Many claimed that Charcot fabricated hysteria by directing his patients. Such accusations were exacerbated by stories of patients such as Blanche Wittman, considered the 'Queen of Hysterics', whose symptoms disappeared after Charcot's death in $1893 .{ }^{17}$

The Iconographie was part of a project to manage and legitimise a complex and questionable disorder, presenting through photographs a clearly defined sequence of movements and expressions that supposedly constituted the hysterical attack. The photographic inclusions would, however, undermine Charcot's research. Hysteria had by then become a disease primarily associated with women. Its etymology is in the Greek word for uterus (hystera), and in early Graeco-Roman medical literature it was 'believed to develop when the female reproductive system was inactive or ungratified over time. ${ }^{18}$ Charcot, in part, held onto the connection between hysteria and frustrated desire, although he shifted focus from the womb to the ovaries, employing a belt-like ovarian compressor as a treatment. ${ }^{19}$ Charcot, however, ultimately wanted to break away from the restrictive, gendered image of hysteria. Although his pioneering studies of hysteria in men opposed 'the gender-differentiated psychologies of the time', he nevertheless oversaw the production of 'some of the most gender-stereotyped images of [the nineteenth] century' ${ }^{20}$ These images were also erotic, whereas, 'on the

E. Bronfen, The Knotted Subject: Hysteria and Its Discontents (Princeton: Princeton University Press, 1998$), 180$.

Wickens, History of the Brain, 255.

5 Hustvedt, Medical Muses, 'Part One'. For a discussion of authors influenced by Charcot, see P. J. Koehler, 'Charcot, La Salpêtrière, and Hysteria as Represented in European Literature' in S. Finger, F. Boller and A. Stiles (eds), Literature, Neurology, and Neuroscience: Neurological and Psychiatric Disorders (Amsterdam and Oxford: Elsevier, 2013), 93-122.

16 Wickens, History of the Brain, 257.

17 Ibid. Wittman remained at the Salpêtrière and become a technician in the radiology department, eventually working with Marie Curie.

18 M. S Micale, 'Charcot and the Idea of Hysteria in the Male: Gender, Mental Science, and Medical Diagnosis in Late NineteenthCentury France', Medical History, 34, 1990, 363.

19 Bronfen, Knotted Subject, 179-80.

Micale, 'Charcot', 410. 
theoretical level, Charcot and his students demonstrated an almost wilful refusal to recognize the possible sexual dimensions of the disorder. ${ }^{21}$ Such ambiguities are perhaps evident in how Charcot characterised the patient Augustine's 'hystero-epilepsy' as ovarian although not 'lecherous' in order 'to distinguish it from desire, so that it [hysteria] could exist as a science. ${ }^{22}$

Looking back at what was happening at the Salpêtrière, one can appreciate that hysteria arose in part from the pressures and limitations placed on women and 'must be understood as a response to stifling social demands and expectations aptly expressed in paralysis, deafness, muteness, and a sense of being strangled. ${ }^{23}$ Hysteria has taken up a strong place in feminist theory and criticism, although Cecily Devereux proposes there is still a need to reclaim 'hysteria' - a need for new definitions and histories that are able to grapple with what has been enacted on women's bodies by patriarchy. ${ }^{24}$ While the hysterical attack perhaps offered a mode of expression to these women, their narratives were ultimately stifled by their physicians. In clinical demonstrations, 'Charcot regularly overruled his patients' pronouncements about actual predisposing experiences in favor of his own hereditary explanations' - a situation De Marneffe suggests was exacerbated by both gender and class divisions as most of these women were poor. ${ }^{25}$

The stereotypical impression of hysteria that emerged from the Iconographie can be understood as an ekphrasis (mind image) produced by the interaction of textual elements (captions, titles, layout, structure) with photographs - an image that is then transferred across generations of readers. The first part of this article centres on how the Iconographie initiated a gendered and sexualised image of hysteria that was taken up in the popular imagination by the surrealists about fifty years later and then re-emerged in Georges Didi-Huberman's 1982 critical study Invention of Hysteria. Through a self-reflexive approach, Didi-Huberman draws attention to how this image inevitably becomes ingrained in interpretive practices. His research additionally foregrounds the role of technological developments in the perception of hysteria.

The second part of this article analyses J. M. Coetzee's 2005 novel Slow Man ${ }^{26}$ to show how the histrionic and gender-stereotyped iteration of hysteria from the nineteenth century remains a readily accessible mode of characterisation in the twentyfirst century. Coetzee's narrative follows sixty-year-old retired photographer Paul Rayment, who struggles to cope after a cycling accident results in the amputation of his right leg above the knee. Neither the words hysteria nor hysterical appear in the text, although the novel is opened up to the photographic history of the Salpêtrière through reference to male patients. The hysteric then enters as the character Marianna. The manner in which she is depicted presents an ekphrasis that can be matched to the vision of hysteria that began with the Iconographie.

\footnotetext{
Ibid., 392.

2 G. Didi-Huberman, Invention of Hysteria: Charcot and the Photographic Iconography of the Salpêtrière, A. Hartz (trans.) (London and Cambridge, MA: MIT Press, 2003), 271.

Hustvedt, Medical Muses, 'Part One'.

C. Devereux, 'Hysteria, Feminism, and Gender Revisited: The Case of the Second Wave', ESC 40, 1, March 2014, 19-45.

'Looking and Listening', 75, 105.

J. M. Coetzee, Slow Man (London: Vintage Books, 2006).
} 
Analysis of the Salpêtrière photographs focuses on the patient Louise Augustine Gleizes, whose photographs connect the phototexts under discussion. Louise ultimately came to be known as Augustine - a name seldom used in the medical literature, where she is referred to as 'X. L., L., X., Gl., Louise, Louise Gl., Louise Gleiz., or Louise Glaiz., and sometimes just G. ${ }^{27}$ Augustine was separated from her parents for most of her life, raised by family members until she was six, and then placed in a convent school until she turned thirteen. Her mother then sent her to live in the home of her employer, referred to in transcripts as Mr C., apparently to take lessons alongside his children. After several attempts to coerce her, $\mathrm{Mr} \mathrm{C}$. threatened her with a razor and raped her. She returned to her parents and suffered her first hysterical convulsions. Upon seeing and evading Mr C. on the street, she experienced an even more violent episode. Augustine worked briefly as a chambermaid but became seriously ill again after learning that her mother was Mr C.s lover and had been complicit in her rape. Augustine entered the Salpêtrière in 1875. Although Bourneville documented that she was fifteen-and-a-half on admission, she had only just turned fourteen. Augustine would re-enact the traumatic events of her life during her attacks. She became one of Charcot's celebrated hysterics, and his most photographed patient, yet she would ultimately find no help from her doctors. Didi-Huberman writes of failed charm as, after a period of good health, Augustine had a severe relapse and became violent, breaking windows and ripping up her straightjacket. Bourneville, he suggests, perhaps gave up on her, and she gave up on her physicians. ${ }^{28}$ Augustine disguised herself in men's clothing and escaped. There are no records of what happened to the real Louise, who instead became the great hysteric of the nineteenth century, to be appropriated thereafter by future generations.

\section{The Phototextual Production of Hysteria}

\section{The Iconographie Photographique de la Salpêtrière}

Photography at the Salpêtrière was not expected to be divorced from artistic value in a bid for objectivity, which one might assume given its use as medical evidence. Charcot was inspired to use photography by the work of G.-B. Duchenne de Boulogne, a physician he greatly admired for his approach to identifying and classifying the clinical features of neurological disorders. ${ }^{29}$ In his 1862 monograph The Mechanism of Human Facial Expression, Duchenne set out to classify human emotions and photographed test subjects, some from the Salpêtrière (although he had no official affiliation to the institution), after triggering facial expressions with electrical currents. ${ }^{30}$ Duchenne regularly compared his photographic work to canonical works of art and included an 'Aesthetic Section' in his monograph for those images he considered

27 Hustvedt, 'Part Three', The case history presented here is adapted from Hustvedt's more detailed account.

28 Invention, 276.

29 Hustvedt, 'Part 3'.

30 G.-B. Duchenne (de Boulogne), Mécanisme de la physionomie humaine ou analyse electro-physiologique de l'expression des passions (Paris: Jules Renouard, 1876). 
'more aesthetic than scientific in appearance. ${ }^{31}$ Charcot too had an artistic sensibility and was skilled at drawing and painting, which had even been a career option presented to him by his father. ${ }^{32}$ Many of the photographs taken at the Salpêtrière were carefully planned and 'touched up', yet Charcot continued to view photography 'as a more perfect extension of the clinician's eye. ${ }^{33}$ For him, photographs did not lose their evidentiary value because of aesthetic manipulation.

Conversely, the realistic details of a photograph did not make it better suited to classifying disease. A few years before Charcot's Iconographie, Jules Bernard Luys published his 1873 Iconographie Photographique des Centres Nerveux - an atlas of 70 photographic prints showing different sections of the brain, accompanied by labelled lithographs of each image. ${ }^{34}$ Sarah de Rijcke suggests that the need to supplement photos with captioned lithographs 'revealed what photographs were not capable of, namely to emphasize the basic characteristics of the brain's gross anatomy. ${ }^{35}$ Photographs are good at capturing an individual specimen's unique physiognomy, but Luys needed to show more general, shared characteristics. While drawings might lack impartiality, they were more suited to representing the neuroanatomist's work: 'A photograph could not reproduce the important details perceived in multiple focal planes and leave out the unimportant ones. ${ }^{36}$ Duchenne in contrast overstated the ability of photographs to establish a more universal link between facial expressions and emotions. Charles Darwin was one of his strongest critics, pointing out that people had trouble identifying the emotions in these images without the use of captions and suggesting that Duchenne's claims thus 'rested more in his complex text-image juxtapositions than in a priori correlations. ${ }^{37}$ Photographs are perhaps, as Hustvedt suggests, 'too alive, too inflected with personality' to articulate the clinical features of a disease. ${ }^{38}$ While the Iconographie was intended as a clinical text, it has since been overwhelmed by a specific type of personality that emerges as the text progresses.

The first image in the Iconographie appears on page 40. It is a drawing of a hand in an exaggeratedly bent position, fingers splayed. The little shading used emphasises the outline of the figure. The fingers are small, suggesting a woman's hand, though this is unclear. One's attention is instead drawn to the deformed shape (symptom). The next drawing, on page 65, shows the full figure of a woman sitting on a chair. Her head and right arm are twisted towards the viewer, resembling Augustine's 'Contracture' pose (see Figure 2). There is no shading to add depth to this simple sketch. The woman's shapeless clothing modestly covers her entire body. Her hair is hidden by a bonnet, and her expression, eyes closed, is peaceful but otherwise nondescript. When one

\footnotetext{
31 H. P. Mauro, 'Duchenne: Discourses of Aesthetics, Sexuality, and Power in Nineteenth-Century Medical Photography', Athanor, 18, 2000, 56.

32 De Marneffe, 'Looking and Listening', 77.

Ibid., 107, 79.

J. B Luys, Iconographie Photographique des Centres Nerveux: Atlas, (Paris: J. B. Baillière et Fils, 1873).

35 S. de Rijcke, 'Light Tries the Expert Eye: The Introduction of Photography in Nineteenth-Century Macroscopic Neuroanatomy', Journal of the History of the Neurosciences, 17, 3, 2008, 358.

36 Ibid., 360 .

37 See Mauro, 'Duchenne', 58.

38 Medical Muses, 'Part Three'.
} 
reaches the end of the text and sees the photographs, they appear even more animated and striking in contrast to the drawings. The interplay of light and shadow creates depth and picks out detail, with some photographs being particularly crisp. The singularity of each figure is marked by age, dress, expression, pose, and so forth.

Augustine first appears in her 'Normal State' (see Figure 1), followed by photographs showing the stages of a hysterical attack. This pattern is repeated in images of other hysteria patients, although there are more of Augustine. In the first image, her expression is pleasant and her body language seems relaxed as she leans against the back of her chair. The flat lighting on her face removes shadow, softening her appearance. The pose she adopts is indicative of a young woman who has been photographed before, perhaps sitting for one of the ubiquitous cartes de visite. ${ }^{39}$ Her clothing is tidy, and one can imagine her adjusting her collar, buttons, and necklace before the photograph was taken as all of these lines are impeccable. The ribbon around her neck extends the covering of her body. This photograph is followed by one showing the onset of an attack. In it, she is strapped to a bed, her mouth monstrously wide open. The image is further disconcerting because it is printed vertically in the Iconographie, as if the bed were propped up. After this singular interlude of horror, the rest of the photographs of Augustine show her in her nightdress, acting out her poses. Consider Figure 2, for example, in which she turns her intense gaze onto the camera. Unlike in Figure 1, her shoulder, arm, and neck are exposed, offset against her dark hair, which itself takes on an aura from backlighting. The image is sensual as her hair drapes over her skin. Her face is rendered sharper by a harsh shadow on one side, and she appears to be pouting. Her gaze is provocative and occupies the focal point of the image. Her twisted hand, unlike in the drawing, is almost an afterthought that one is directed towards by the caption, 'Contracture'.

By showing well-delineated poses, the photographic sequence conveys Charcot's insistence on the uniformity of the hysterical attack. In actuality, Augustine's attacks were more chaotic than the Iconographie suggests and often aborted, meaning the sequence was interrupted. ${ }^{40}$ In Figure 1, Augustine's appearance is so far removed from the others that it casts doubt on whether the other photographs were created during the same attack. The 'Normal State' image also gives a sense of self-possession in contrast to the images of the attack, during which her dramatic poses make her seem like another person. It was, however, the striking and unsettling beauty of the latter, of her hysterical identity, that would capture the imagination of the surrealists, who isolated and extracted hysteria's erotic iterations and sensationalised them for public consumption in the twentieth century.

\section{La Révolution Surréaliste}

In 1928, surrealists Louis Aragon and André Breton published six photographs of Augustine in the periodical La Révolution Surréaliste, in an article celebrating what 
they felt was the fiftieth anniversary of hysteria, ${ }^{41}$ even though Charcot had been working on the disease for some years prior to the publication of the Iconographie, and one of the photographs of Augustine is dated 1876. Was this an oversight or did the surrealists mean to mark the discovery retrospectively by this anniversary, making it their own discovery? The surrealists were fascinated by the figure of the 'madwoman' and, in the same issue, Breton published extracts from his 1928 work, Nadja. The text is an autobiographical account of Breton's encounter with a mentally-ill woman (who would become an icon of female madness in surrealism) and includes 'a diatribe against institutional psychiatry'. ${ }^{42}$ Linda Steer proposes that to the surrealists Augustine represented 'freedom from rational thought and from positivism. ${ }^{43}$ As if wrenching the illness from the physician's grasp, they declare hysteria to be 'the greatest poetic discovery of the end of the nineteenth century, and this at the very moment when the dismemberment of the concept of hysteria appears to be a consummated thing. ${ }^{44}$ The surrealists thereby 'reinterpreted the medical gaze within a configuration in which the therapist no longer occupied a position of mastery' and claimed hysteria as 'a language, a means of expression, a work of poetry whose subversive form ought to be championed against art itself, against literature. ${ }^{35}$

The impression of hysteria that Breton and Aragon grasp and transfer to their periodical is sensual and exotic. They aptly use the term 'consummate', with its sexual undertones, to mark the end of hysteria as a diagnosis and the beginning of its poetic identity. They exclude both the modest photograph of Augustine in her normal state and the macabre photograph showing the onset of the attack. Instead, they reprint the more aesthetic photographs of her in her nightdress and group these under the title 'Attitudes Passionnelles' (Passionate Attitudes) without any of their original captions. In the attitudes passionnelles, the third phase of the hysterical attack specified in the Iconographie, Augustine took on roles and even drew from religious iconography - mimicking the crucifixion for example. Steer suggests that the surrealists' selection acts as a mockery of both religion and science - as if 'hysteria finds religion in science' - and furthermore plays down the suffering of hysteria by choosing photographs that are 'odd, perhaps humorous or attractive. ${ }^{46}$ The series overall emphasises Augustine's 'sexual availability'. ${ }^{47}$ Perhaps also telling is the surrealists' inclusion of 'Contracture' (Figure 2), which is not part of the attitudes passionnelles stage in the Iconographie. By placing the photograph within this category, her expression is marked as 'passionate'.

\footnotetext{
41 L. Aragon, and A. Breton, 'Le Cinquantenaire de L'Hysterie (1878-1928)', La Révolution Surréaliste, 11 March 1928, $20-2$.

42 N. Lusty, 'Surrealism's Banging Door', Textual Practice, 17, 2, 2003, 341. Breton had medical training and cared for shell-shock victims during the First World War. For a discussion of how his relationship with the famed neurologist Joseph Babinski influenced his thinking, see J. Haan, P. J Koehler, and J. Bogousslavsky, 'Neurology and Surrealism: André Breton and Joseph Babinski', Brain: A Journal of Neurology, 135, 2012, 3830-8.

43 L. Steer, Appropriated Photographs in French Surrealist Periodicals, 1924-1939 (New York: Routledge, 2017) unpaginated ebook https://books.google.co.za/books?id=JikxDwAAQBAJ\&dq=L.+Steer,+Appropriated+Photographs+in+French+Surrealist+Peri odicals,+1924-1939\&source=gbs_navlinks_s (accessed 20 August 2020).

44 L. Aragon and A. Breton, 'Le Cinquantenaire', 20. Translated for this article by Patricia Hayes.

45 E. Roudinesco, Jacques Lacan \& Co: A History of Psychoanalysis in France, 1925--1985 (Chicago: University of Chicago Press, 1990), 7.

46 Steer, Appropriated Photographs.

47 Ibid.
} 
Photographs of hysterical attacks also seem to accord with the surrealist fascination for 'convulsive beauty' - a concept Breton used at the end of Nadja, declaring 'Beauty will be convulsive or will not be at all'. ${ }^{48}$ 'Convulsive beauty', as observed by Kirsten Hoving Powell in a study on Man Ray, brings together ideal form with unexpected and sometimes even grotesque distortion to create a new being. ${ }^{49}$ In an edition of La Révolution Surréaliste from 1925, for example, Man Ray's photograph of a pale nude with a large shadow over her face and crotch becomes 'a mysterious faceless, footless body'; what would otherwise be a beautiful nude is transformed (or deformed) 'into a filmy, hallucinatory state of being. ${ }^{50}$ The photographs of Augustine, however, fail to test the limits of this concept in favour of aesthetic appeal. She remains mostly beautiful and sensual, far from crossing the boundary that could lead to repulsion. Despite their assertion that hysteria is 'a supreme means of expression, ${ }^{51}$ Breton and Aragon reiterate and augment a stereotypical impression of hysteria. Augustine emerges from La Révolution Surréaliste as an enigmatic and captivating specimen, placing those who encounter these phototexts in a difficult space.

\section{The dark-haired beauty}

Ulrich Baer warns of the ethical dangers of engaging with the photographs from the Salpêtrière, writing, 'If we want to unfetter the hysterics from the master's darkroom, we must risk aligning our own gaze with Charcot's. ${ }^{52}$ However, the gaze we risk aligning ourselves with is not entirely Charcot's. As noted, the image of hysteria that emerges from the Iconographie is different from how Charcot wished to characterise the illness. It is instead hysteria's erotic, artistic, and gendered manifestations that continue to be transferred, even by those who approach the photographs with ethical intentions. This is the predicament illuminated by Didi-Huberman's monograph on the Salpêtrière images.

Didi-Huberman first came across photographs of Augustine by chance in a small cafe and was fixated by their disquieting charm, recalling: 'They were troubling, even painful, to contemplate. All it took was this first encounter to understand their power, their strangeness, and the challenge they presented; pain was at work here, but where exactly did it lie in the image? ${ }^{53}$ In attempting to grapple with this elusive pain, he knowingly surrenders himself to the 'paradox of atrocity' of the physician who is compelled 'to observe, as an artist, the luxurious pain of a body in the throes of its symptoms. ${ }^{54}$

Didi-Huberman marks us as accomplices in making Augustine into hysteria's alluring star and icon. Before one sees the image of Augustine in her normal state

48 A. Breton, Nadja, R. Howard (trans.) (New York: Grove Press, 1960).

49 K. H. Powell, “Le Violon d'Ingres”: Man Ray's Variations on Ingres, Deformation, Desire and De Sade', Art History, 23, 5, December 2000, 772-9.

50 Ibid., 780.

51 Aragon and Breton, 'Le Cinquantenaire', 22.

52 U. Baer, Spectral Evidence: The Photography of Trauma (Cambridge, MA: MIT Press, 2002), 28.

53 G. Didi-Huberman, 'Of Images and Ills', Critical Inquiry, 42, Spring 2016, 441.

54 Didi-Huberman, Invention, 4. 
(Figure 1), he writes, 'Here, gentlemen, is Augustine, your favorite case. ${ }^{55}$ His reference to 'gentlemen', without specifying whether he is addressing her physicians at the Salpêtrière, places Augustine beneath a wider and more inclusive gaze, comprising physicians, surrealists, and the art critic himself. The name Augustine is also used with some complicity as it has come to define her after multiple appropriations of her image. In seeing her, Didi-Huberman cannot move past her illness and its symptoms. He plays on the double meaning of 'pose' (representing both the model's pose and photographic exposure) and stresses that her right arm must 'adopt the appropriate pose, since at the time, Augustine was for the most part wholly unable to use or control this arm. ${ }^{36}$ Aligned to this description, the photograph of Augustine in her normal state first appears in Didi-Huberman's monograph in a cropped and enlarged version: her face and the hand she rests it on fill the frame. Her arm is not visible much below her wrist, and only the top three buttons of her dress are seen. As if in reversal of the 'zoom out' that gradually enters the Iconographie through its drawings (from contorted hand to full figure), Didi-Huberman narrows the reader's focus, zooming in. By enlarging her face, he brings her psychologically closer to the viewer, letting us confront the gaze of Augustine.

Didi-Huberman's text also allows us to see how the woman who was Louise has been completely subsumed by the image of Augustine. In looking at Augustine's normal state, Didi-Huberman guides us to focus on how her hair in the photograph is barely discernible as the blond that Bourneville documents. ${ }^{57}$ At the time of this portrait, Régnard was working with the slow wet-collodion process. Rather than failure, Didi-Huberman sees the darkness as 'the procrastination of photographic revelation, thus the temporal retreat of light. ${ }^{58}$ The light withdraws still further in Invention. In the paperback edition referenced here, the reprint is darker than it appears in the Iconographie. In both the cropped photograph and the subsequent full-size print of Augustine in her normal state, ${ }^{59}$ there is less contrast between the foreground and background. Her hair seems to merge into the dark space around her, as if she is fusing into the image. The loss of perspective is perhaps metonymic for the grander loss of perspective that occurred when Louise (an ill woman) came to stand for an illness itself, becoming its exotic avatar.

Didi-Huberman thus finds himself in an impasse of care and complicity: of being forced to reinforce these images in order to find the pain they hide. The pattern remains evident in other adaptations of Augustine's story. The dark-haired beauty returns in at least two works that offer feminist critiques of the power dynamics between Augustine and her physicians. Anna Furse's 1997 play Augustine (Big Hysteria), reenvisions the events at the Salpêtrière from Augustine's perspective, ${ }^{60}$ depicting how

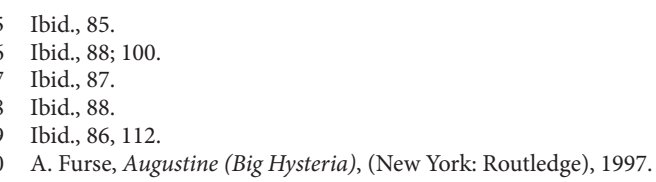


she 'begins to reject the doctors' attempts to direct her behavior as she becomes more and more aware of the fact that they abuse her as an instrument to affirm their theories. ${ }^{61}$ Yet this text also reaffirms her entrapment in the Salpêtrière's iconography by 'project[ing] historical photographs, probably taken from the Iconographie Photographique, of Augustine's hysterical fits onto the stage.'.2 Alice Winocour's 2012 film Augustine depicts how Augustine (here aged 19) is coerced into the role of star hysteric in the hope of being cured. ${ }^{63}$ Some scenes in the film restage images from the Iconographie (such as Augustine stretched across two chairs), but Winocour also attempts to reverse the physicians' gaze, showing Augustine scrutinizing Charcot while he works at his desk. Winocour's dark-haired heroine repeatedly asks when she will be cured, yet her physical symptoms ultimately disappear not through Charcot's intervention but after a series of accidents. During her final performance of hysteria on Charcot's lecture stage, she secretly lets him know that she has regained control of her body and shows him how she can now simulate an attack.

Augustine's dark hair is also a marker of the role technology played in creating her legacy. Beatriz Pichel reminds us that at the Salpêtrière the image was intended as a medical procedure that was 'regulated and shaped by medical practices and the materiality of changing photographic technology ${ }^{64}$ Paul Régnard was later replaced by Albert Londe, who became head of photographic services in 1884. Londe developed new techniques and devices (even inventing cameras) as well as putting in place protocols for continuity. His approach significantly altered the aesthetic of these photographs: 'Women in ordinary day-to-day clothes performing onstage [were] to replace the sexualized images of women in nightdresses on beds ${ }^{65}$ More recent changes in technology have, however, turned the tide again.

The figure of the hysteric has been consumed by an iconography that is now easily accessible online. Search Google and you will find many reproductions of Augustine's photographs. Captions are now abridged as search terms. The ubiquity of images in the digital space creates what Renate Brosch describes as 'an enlarged cultural memory of images. ${ }^{66}$ The continual return of the Iconographie's depiction of hysteria is perhaps an indication that it never actually disappeared. Even though the diagnosis is no longer used, many remain receptive to hysteria's stereotype because, as Hustvedt points out, modern medicine 'continues to perpetuate the idea that the female body is far more vulnerable than its male counterpart. Premenstrual syndrome, postpartum depression, and "raging hormones" are among the more recent additions to a medical mythology that is centuries old. ${ }^{67}$ In her overly sexualised and erratic state, the hysteric continues to move through phototexts.

61 Koehler, 'Charcot', 117

62 Ibid., 116-17.

63 Augustine, directed by Alice Winocour (France: Dharamsala, France 3 Cinéma, ARP Sélection, 2012).

64 B. Pichel, 'The Backstage of Hysteria: Medicine in the Photographic Studio', Remedianetwork, 16 January 2017, remedianetwork.net/2017/01/16/the-backstage-of-hysteria-medicine-in-the-photographic-studio/ . (accessed 10 May 2020).

65 Ibid.

66 R. Brosch, 'Ekphrasis in the Digital Age: Responses to Image', Poetics Today, 39, 2 June 2018, 229.

67

Medical Muses, 'Part One'. 


\section{A Next Generation of Hysteria: The Case of Slow Man}

\section{Photographic reproduction}

The Iconographie and Slow Man are a world and a century apart yet connected through the stereotypical ekphrasis of hysteria inhabited by Augustine and, in Coetzee's text, the blind Marianna, an enigmatic character who enters and leaves the text abruptly. The medium of photography is important in the novel. Paul Rayment is a retired photographer who owns a large collection of postcards and photographs showing 'life in the early mining camps of Victoria and New South Wales. ${ }^{38}$ Many of these images are credited to Antoine Fauchery, who was a real nineteenth-century photographer, though it is unclear whether Coetzee modelled any of the fictional Faucherys in the novel on specific, extant images. ${ }^{69}$ Paul's life takes a metafictional twist with the sudden appearance of famous author Elizabeth Costello, who seems to be writing his story. Paul falls in love with his nurse Marijana Jokić and tries to befriend her teenage son Drago, even offering to pay his tuition at an exclusive school. Paul, who is originally from France, regards his photographs as potential sites of belonging, hoping that his experience as an emigrant links his history not just to Marijana [who is from Croatia] and her family, but to the members of the early immigrant communities in Australia. ${ }^{70}$ Yet, he must concede the possibility that 'the history that he wants to claim' belongs instead to 'the English and Irish. ${ }^{71}$ If one reads beyond these explicit desires, Paul's responses to the photographs intimate at deeper anxieties that he projects onto the female body, initially revealed in his thoughts about Marijana Jokić. This way of seeing the world then merges with the tropes around hysteria when he meets Marianna.

In At the Edge of Sight, Shawn Michelle Smith offers a suggestive reading of Roland Barthes's famous Camera Lucida, examining how his descriptions of photographs reveal anxieties about race and reproduction as he struggles with his own childlessness in the wake of his mother's death. ${ }^{72}$ After the amputation of his leg, Paul finds himself succumbing to depression and also fixates on 'dying childless'. His subsequent attraction to Marijana Jokić is predicated on the thought that she could have saved him from 'childlessness. ${ }^{73}$ Feeling jealous, Paul thinks invasively of how her husband 'has the children who come with her, come out of her." ${ }^{74}$ This leads him to reflect on the photographic collection he will leave behind as a bequest to the State Library in Adelaide. What Paul then fails to articulate is that he finds Marijana's foil in a photograph he feels unable to show to her. This Fauchery that 'haunts him most deeply' reveals a dismal scene:

68 Coetzee, Slow Man, 47-8.

69 In 1857, Fauchery collaborated with Richard Daintree to produce the photo series 'Sun Pictures of Victoria', which depicts 'goldfields, Melbourne Streets, landscapes and portraits of Indigenous Victorians'. State Library of Victoria, 'Early photographs: Gold', CultureVictoria, https://cv.vic.gov.au/stories/a-diverse-state/early-photographs-gold (accessed 20 May 2020 ).

70 D. Powers, 'Emigration and photography in J. M. Coetzee's Slow Man', Journal of Postcolonial Writing, 49, 4, $2013,462$.

71 Coetzee, Slow Man, 52.

72 S. M. Smith, At the Edge of Sight: Photography and the Unseen (Durham and London: Duke University Press, 2013).

73 Coetzee, Slow Man, 20, 34.

74 Ibid., 51. 
It is of a woman and six children grouped in the doorway of a mud and wattle cabin. That is to say, it could be a woman and six children, or the eldest girl could be not a child at all but a second woman, a second wife, brought in to take the place of the first, who looks drained of life, exhausted of loins.

All of them wear the same expression ... frightened, frozen, like oxen at the portal of a slaughterhouse. ${ }^{75}$

The woman in the photograph was, like Marijana Jokić, capable of bearing many children, yet she is now 'exhausted of loins'. The suggestion that the eldest girl might be a second wife intended 'to take the place of the first' gives the impression of a steady supply of female bodies brought in to sustain population growth. There was indeed a demand for women in the Australian colonies in the mid 1800s. Joseph A. Robins recounts how, over a two-year period, almost four thousand orphan girls were transported to Australia from Irish workhouses. ${ }^{76}$ The derogatory comparison of the figures in Paul's Fauchery to oxen, domestic animals used for breeding, reiterates how their value is predicated on fulfilling biological needs. If the history Paul wants to share with Marijana comes, as he asserts, from 'grinding labour on hollow stomachs, ${ }^{37}$ then labour should refer to childbirth too. The woman and children are grouped as if 'at the portal of a slaughterhouse', yet they face outwards rather than in. Their clustering within the doorframe gives the sense they are held in place: framed within the frame of the photograph itself. This woman has given Paul progeny inadvertently: the image of her and the children is rare, expensive, and could be his way of having his name remembered. Biological issue is thereby replaced with a photographic reproduction.

Paul expects the photograph to perform a specific function but will find, as the doctors at the Salpêtrière did, that he cannot control the medium. He asserts that photographs 'leave the darkroom ... fixed, immutable', yet by his own admission he has restored images that were 'in poor condition. ${ }^{\text {' }}$ Furthermore, while reading a book by Elizabeth Costello, the author who suddenly comes to stay with him, he is reminded of entropy (a 'gradual decline into disorder ${ }^{79}$ ), which he concedes 'is irreversible and irrevocable and rules the universe. ${ }^{80}$ Paul is also confronted by the uncontrollable nature of the dissemination of images when Drago replaces several of his prints with digital reproductions. Paul is incensed to the point of destroying the goodwill he has tried so hard to cultivate with the family. He confronts Marijana and demands that Drago return the 'original prints' that were 'touched by Fauchery's hand, ${ }^{81}$ reiterating his desire that the photographs should remain singular, owned by

Ibid., 51-2.

76 J. A. Robins, 'Irish Orphan Emigration to Australia 1848-1850', Studies: An Irish Quarterly Review, 57, 228, Winter 1968, $372-87$.

77 Coetzee, Slow Man, 52

78 Ibid., 64; 176.

79 'Entropy', Lexico, www.lexico.com/definition/entropy (accessed 30 August 2020).

80 Coetzee, Slow Man, 119.

81 Ibid., 250. 
him alone. Paul views digital photographs as 'images without substance, images that could flash through the ether without residing anywhere. ${ }^{2}$ The metaphor of ether parallels the phenomenon of ekphrasis, through which a mind image is transferred. It is a reminder that the novel itself contains no actual photographic prints - no indexical ties to a specific historical moment (the Faucherys in Slow Man are fictitious). The photographic frame is open and unstable. Although Paul wants to be part of an Australian lineage, he is instead pulled into another photographic history, in which the hysteric resides.

\section{Mirroring}

The Salpêtrière's far-reaching cultural memory enters the novel when Paul contemplates the reflection he refuses to meet:

The face that threatens to confront him in the mirror is that of a gaunt, unshaven old tramp. In fact, worse than that. At a bookstall on the Seine he once picked up a medical text with photographs of patients from the Salpêtrière: cases of mania, dementia, melancholia, Huntingdon's chorea. Despite the untidy beards, despite the hospital nightshirts, he at once recognised in them soul mates, cousins who had gone down a road he would one day follow. ${ }^{83}$

Mirrors, photographs, and literature have a longstanding relationship. The daguerreotype (one of the first photographs, made public in 1839) was formed on a highly reflective surface. Referred to as a mirror with a memory, it was soon incorporated into literature as a mirroring device for both character and reader. ${ }^{84}$ Paul's reflection is not a straightforward insight into his condition but rather a double image: he overlays the vision of his own face with memories of photographs from a medical text. His greying appearance - gaunt and unshaven - matches these images aesthetically and echoes an earlier description of Paul as 'greyer and drearier' since the accident, as well as Elizabeth's warning that his life will be consumed by 'a grey monotone. ${ }^{85}$ It is as if Paul were entering the photographic frame.

This running analogy extends to a comparison between Paul's accident and the act of being photographed. The impact he feels is 'like a bolt of electricity' and it places him in a dissociative state as 'he hears rather than feels the impact of his skull', and he wakes only momentarily, worried his bicycle might 'disappear in a flash' ${ }^{86}$ - like the flash of a camera. The event is never fully integrated into his consciousness, and he later asks Elizabeth whether he 'failed to grasp ${ }^{87}$ what happened. Baer's description

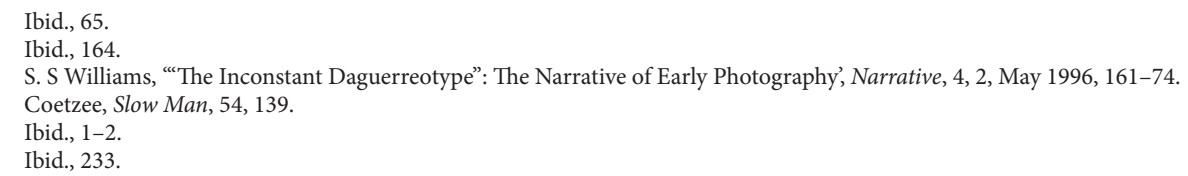


of photographic capture and trauma is notably similar. For Baer, the flash assaults the subject unexpectedly 'with the violence of the lightning bolt', and its disorientating effect means that 'the subsequent cognitive effort may not fully integrate the moment of disorientation into memory' ${ }^{88}$ Reflecting on the accident, Paul perceives how time seems to stop until, 'hey presto, one emerges into a second world identical with the first, where time resumes and the action proceeds. ${ }^{89}$ It is as if his picture is taken ('hey presto') and he emerges in a replica world, narrated through the language of photography, furthering the sense that he is becoming part of the photographic space of the Salpêtrière.

\section{Marianna's performance}

Marianna has all of Augustine's exoticism. Paul first sees her in a hospital elevator. Her dress is inside out, the upper half of her face is hidden by a broad hat and sunglasses, and she is being led by an elderly woman 'with a hawklike nose. The narrative that comes to his mind is of 'the crone leading the hastily clad princess in an enchanted sleepwalk. ${ }^{90}$ Marianna is like a hypnotised hysteric being led onto the stage at one of Charcot's Tuesday lectures. Paul wonders what happened to her face and feels a strong desire for her, dreaming of her. His response intimates at 'convulsive beauty' suggested earlier in an ekphrasis describing the Venus de Milo, whose missing arms render 'her beauty more poignant.91 Marianna's injury also makes her into a new, captivating being. Paul's body too becomes a disturbing work of art after the amputation. He pictures his bandaged limb as 'a wooden shaft with a barb at its head like a harpoon and rubber suckers on its three little feet. It is out of Surrealism. It is out of Dali.' ${ }^{2}$ The image is absurd to the point that his truncated leg actually has three feet of its own. What would be a source of surrealist fascination is, for Paul, indicative of revulsion and his sense of disembodiment.

In contrast, Elizabeth characterises Marianna's deformity (one eye lost, the other blind) as both morbidly fascinating - 'one finds oneself staring and then withdraws one's gaze' - and part of a deep eroticism: 'She wants to hide herself. She wants to die. And at the same time - she cannot help herself - she is full of unhappy lust. She is in the summer of her womanly life; she moans aloud with lust, day after day, like a cow or a sow in heat. ${ }^{\prime 93}$ Marianna's crisis is reconfigured as the problem of intense, unsatisfied sexual desire. The idea that she is writhing with lust everyday like an animal 'in heat' echoes references to hysteria, in texts as old as Plato's, where the uterus is described 'as a restless animal, raging through the female body due to unnatural prolonged continence. ${ }^{94}$ On this point, Charcot's work is somewhat ambivalent, but he wished to avoid the hyper-sexualised image we see in Coetzee's Marianna, who

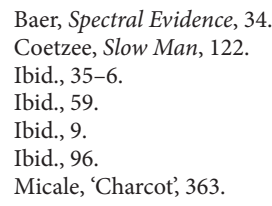


craves 'love in its most physical expression..$^{95}$ Like the figures in the Fauchery image, Marianna is equated with an animal used for breeding. This characterisation is an extension of what might be considered a 'hysterical' gaze - a gaze that penetrates the image (or imagined image) of a woman to reach her hystera (uterus).

Elizabeth arranges a sexual encounter between Paul and Marianna in his apartment. Before Marianna arrives, Elizabeth covers Paul's eyes with a strange paste that hardens under a cloth. Like the photographer Fauchery, who 'plunged his head under the dark cloth ${ }^{96}$ before photographing the exhausted woman and her children, Paul's face is covered in preparation for Marianna. Paul Rayment and Paul Régnard, two photographers with eerily similar names, receive the hysteric at the behest of a director (Costello, Charcot). Paul and Marianna 'are on stage, in a certain sense, ${ }^{97}$ ready to perform for the authority who will attempt to document the event and place it within a specific narrative. Elizabeth, however, appears to be a capricious narrator as she insists that Paul pay Marianna, seemingly contradicting her earlier assertions that Marianna is desperate to fulfil a physical desire.

The scene is underpinned by references to scientific curiosity, described as 'like a primitive experiment in biology - like bringing different species together to see if they will mate. ${ }^{98}$ This furthers the humiliating analogy of Marianna as an animal, and places both her and Paul under a scientific (clinical) gaze. He unzips her dress down to her waist and she sits beside him, half-naked and trembling as medicine and art come together beneath the camera's gaze for a 'biologico-literary experiment':

A minute passes. Nothing more happens. A one-legged man and a partially disrobed woman waiting for what? For the click of a camera shutter? Australian Gothic. Matilda and her bloke, worn down by a lifetime of waltzing, parts of their bodies falling off or falling out, face the photographer one last time. ${ }^{99}$

The novel again turns each character, to borrow Didi-Huberman's formulation, into 'a living work of art.' ${ }^{100}$ They 'face the photographer' rather than each other, as if posing for a camera. The term 'Australian Gothic' adapts the title of Grant Wood's famous 1930 painting American Gothic, which also shows a rigid couple facing the observer directly. ${ }^{101}$ Like statues, Paul and Marianna break apart: his leg falling off and her eye falling out. The medley of metaphors underscores the confusion they feel in this awkward encounter that is itself hard to define. After they then have sex, Paul cannot forget Elizabeth's earlier characterisation of Marianna, observing how

95 Coetzee, Slow Man, 97.

96 Ibid., 52.

97 Ibid., 103.

98 Ibid., 108

99 Ibid., 114, 108. Michelle Kelly offers a compelling reading of intermedial references in the novel, describing how this scene is 'framed as a piece of theatre or opera being performed by Paul and Marianna'. M. Kelly, 'Other Arts and Adaptations' in J. Zimbler (ed), The Cambridge Companion to J. M. Coetzee (Cambridge: Cambridge University Press, 2020), 199.

101 Art Institute of Chicago, https://www.artic.edu/artworks/6565/american-gothic (accessed 10 May 2020). 
the 'sole intimation ... of either raging thirst or raging huger comes in the form of an unusual but not unpleasing heat at the core of her body, as though her womb or perhaps her heart were glowing with a fire of its own. ${ }^{102}$ While heart, as an afterthought, at least intimates that the narrative should move away from the fixation on her womb, it also signifies a need to read her through her physical body. When Paul then tries to speak to her of Elizabeth, suggesting flippantly that they are an entertainment, Marianna almost laughs but then breaks down into tears. ${ }^{103}$ It seems that her heat dissipates as she settles into the sadness that characterised the final phase that Charcot identified in a hysterical attack: when the hysteric begins to regain consciousness but remains 'in a state of melancholy ... displaying loud crying and sobbing, lamentation, or laughter. ${ }^{104}$

Like Augustine, Marianna leaves the story abruptly, walking away from the photograph and not returning to the novel. Zoë Wicomb casts their last strange scene as 'a dark cul-de-sac in the narrative', noting that Marianna seems to become 'a character whom the author fails to develop and thus has to abandon. ${ }^{105}$ The term develop is apt to the photographic analogy shaping the scene. Marianna and Paul are not actually photographed: the image of them together is never developed in a darkroom but is rather a visualisation without a physical form, an image for the ether of ekphrasis. Within this ephemeral realm of mind images transferred across generations, Marianna's virtual image overlays those taken at the Salpêtrière - photographs then ushered into cultural memory and digital archives. Marianna and Augustine thereby come to share the readily accessible trope of the disturbed yet sexualised hysteric, who continues to carry the burden of reproductive anxieties through photographic reproductions.

\section{Acknowledgments}

This work is based on the research supported by the South African Research Chairs initiative of the Department of Science and Innovation and National Research Foundation of South Africa (NRF), (Unique Grant No 98911).

I acknowledge the Centre for Humanities Research (CHR) of the University of the Western Cape for the fellowship award that facilitated the writing of the present article. The opinions expressed and conclusions reached are my own and not necessarily attributable to either the CHR or the NRF.

\footnotetext{
102 Coetzee, Slow Man, 109.

103 Ibid., 112.

104 Bronfen, Knotted Subject, 181-2.

105 Z. Wicomb, 'Slow Man and the Real: A Lesson in Reading and Writing', Journal of Literary Studies, 25, 4, $2009,17,15$.
} 